\title{
Transformation Process in Estonia: A Challenge for Social Policy
}

\author{
AVO TRUMM
}

Research Associate

Unit of Family Research

Tartu University, Estonia

\section{DAGMAR KUTSAR}

\section{Research Associate}

Unit of Family Research

Tartu University, Estonia

\section{URMAS OJA}

\author{
Research Associate \\ Unit of Family Research \\ Tartu University, Estonia
}

\begin{abstract}
The aim of this study is to analyze the new economic situation households have to face in Estonia and to discuss the new tasks and responsibilities of social policy in this new situation. The data used are based on a sample of 419 households monitored in January 1993.

The study reveals that low income and unequal income distribution is characteristic of today's Estonia. The average salary of households has continuously increased but the increase has all the time been lower than that of the cost of living.

The article discusses the new socio-political tasks and responsibilities. The main task is to reach the optimal balance of limited resources between economic development and social expenditures. The state has to support disabled people who cannot work but it cannot take the responsibility of guaranteeing a minimum of living for everyone.
\end{abstract}

Keywords: households, income, social policy, Estonia

"Changing the entire political, economic and social system in a society is difficult. And if the changes are to be brought about simultaneously, the situation becomes nearly insoluble" (Dellenbrant 1993, 154).

Estonia restored independence after fifty years of the Soviet occupation in 1991. Now, building a new society, she faces deep crisis in all spheres of the society. Coping with multiple social change and economic survival are essential tasks for many people, families and the whole country. 
The collapse of the Soviet order brought to an end not only a particular type of a political and economic system, but a particular type of welfare state. New social phenomena such as unemployment, inequality and poverty have found a fertile soil in Estonia. The new socio-political and economic conditions set new tasks, create new dilemmas and challenge for socio-politicians.

The transformation and its consequences in Eastern Europe have great importance for those involved in this process as well as for the developed western countries. The different aspects of reformation are discussed at numerous political meetings and presented at scientific conferences. Several articles are published on this issue by the eastern and western scholars (Deacon 1992, Marklund 1993, Dellenbrant 1993, Ferge and Kolberg 1992, Marody 1992). The barriers of transformation have been in the focus and the negative scenarios are outlined (Dellenbrant 1993).

The aim of the present study is dual:

1) to analyze the new situation people in Estonia have to meet focusing on the economic situation of households;

2) to discuss new tasks and responsibilities of social policy in a changed situation.

\section{Data and method}

In 1991 the method of household budgets was developed by the Unit of Family Research at Tartu University in close cooperation with the joint stock company "EMOR". The sample of 2000 households is divided into three groups and every group is involved in the household monitoring once in three months, i.e. four times a year. The sample is corrected every quarter and renewed every year. The data are collected by EMOR Ltd. and handed over to the Estonian Statistics Authority. lyzed.

Currently the data about 419 households monitored in January 1993 will be ana-

\section{Concept of household}

The household is identified by the persons living together and having a joint budget. An adult member of the household as a contact person in the survey writes down all the incomes and expenditures the household makes every day during one month.

\section{Concept of household disposable equivalent income}

Household income is a sum of incomes of individual members, transfers and services that a household receives. The concept of disposable income is of central significance in the analysis of household economic welfare. Calculation of disposable income follows a scheme that is exposed by Hannu Uusitalo $(1992,20)$

Factor income

+ Received public sector transfers

$=$ Gross income

- Income taxes

$=$ Disposable income

Economic welfare is dependent on the size and structure of the household. For elimination this impact the method of consumption units is needed. The consumption unit is determined using the OECD scale. It is internationally widely used authoritative ex- 
ample of the result of the expert method and gives an opportunity to reduce full households into consumption units. OECD concept of consumption unit (equivalence scale) proceeds from the fact of cohabitation (household). The first adult has a value 1.0, other adults 0.7 and children 0.5 (Uusitalo 1992, 17). Disposable income calculated on the basis of OECD equivalence scale forms household disposable equivalent income.

\section{Analysis}

\section{The income distribution of the households}

Low income and its unequal distribution is characteristic of today's Estonia. In January 1993 in about two thirds of monitored households the disposable income per consumption unit was less than two minimum wages, i.e. less than EEK 600. The average salary of households has continuously increased (in January 1993 the average salary was EEK 755, in June EEK 1,080), but all the time it has been lower than the increase of the cost of living. Compared with the salaries in July 1992 the real salary in June 1993 forms $94.5 \%$. Figure 1 illustrates the distribution of income and the structure of the income in different income groups in January 1993. The income share of the total income distribution in the lowest decile forms $3.1 \%$ (the last $27.3 \%$ ). (1 USD = ca 13 EEK in 1993)

Fig u re 1. The structure of disposable household income per OECD consumption unit in income deciles in January 1993.

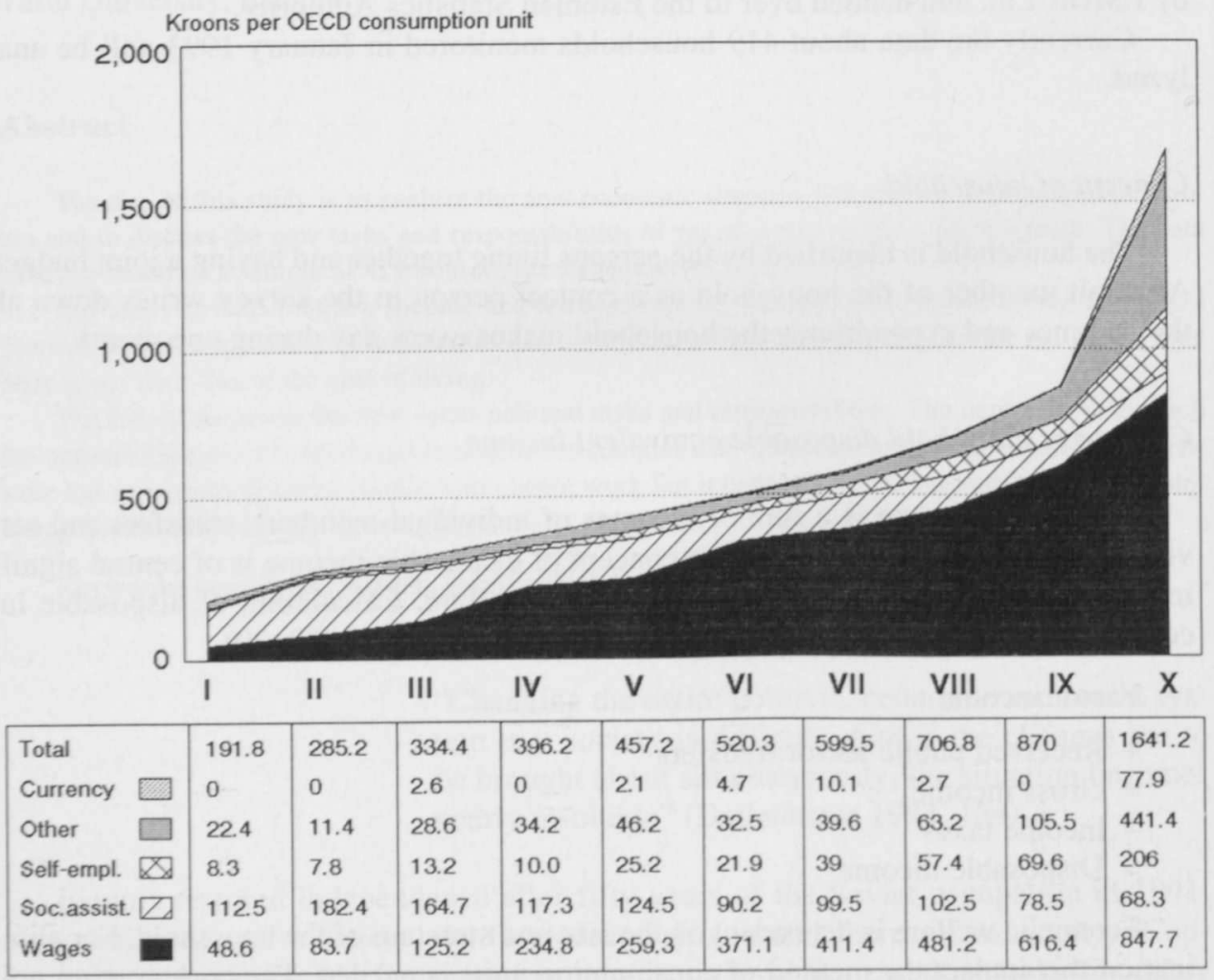

Household deciles are calculated on the basis of disposable income per OECD 
The income structure in the upper and the lower deciles differs markedly. In the bottom income groups, compensations and allowances occupy the major part, the upper income groups receive more from property, from the production of goods and services (Figure 1). Those are the people who are doing well: they have initiative, they are successful and they know how to control the situation. Their resources are their age, ability to develop and look for new perspectives. The lower income groups are dependent on social transfers and they have problems of economic survival. Proceeding from the income structure they have low enterprising spirit and ability to cope with rapid changes. Those are mainly the people in retirement age, single parents, the unemployed and families with many children.

\section{Consumption structure}

The grouping of households by the amount of expenditure gives evidence of existing different levels of economic welfare. The differences in the amount of expenditure are about eight times between the households which are situated in the first and the last decile (Figure 2). Consequently, the household groups with modest expenditures, average and high level of expenditure have a different expenditure structure (Figure 3).

Proceeding from the structure of the expenditures which the respondent households have made in January, a deformed structure of consumption is revealed. Almost all the households (the upper tenth excluded) have a rather similar consumption struc-

F i g u r e 2. The structure of household consumption in expenditure deciles in January 1993.

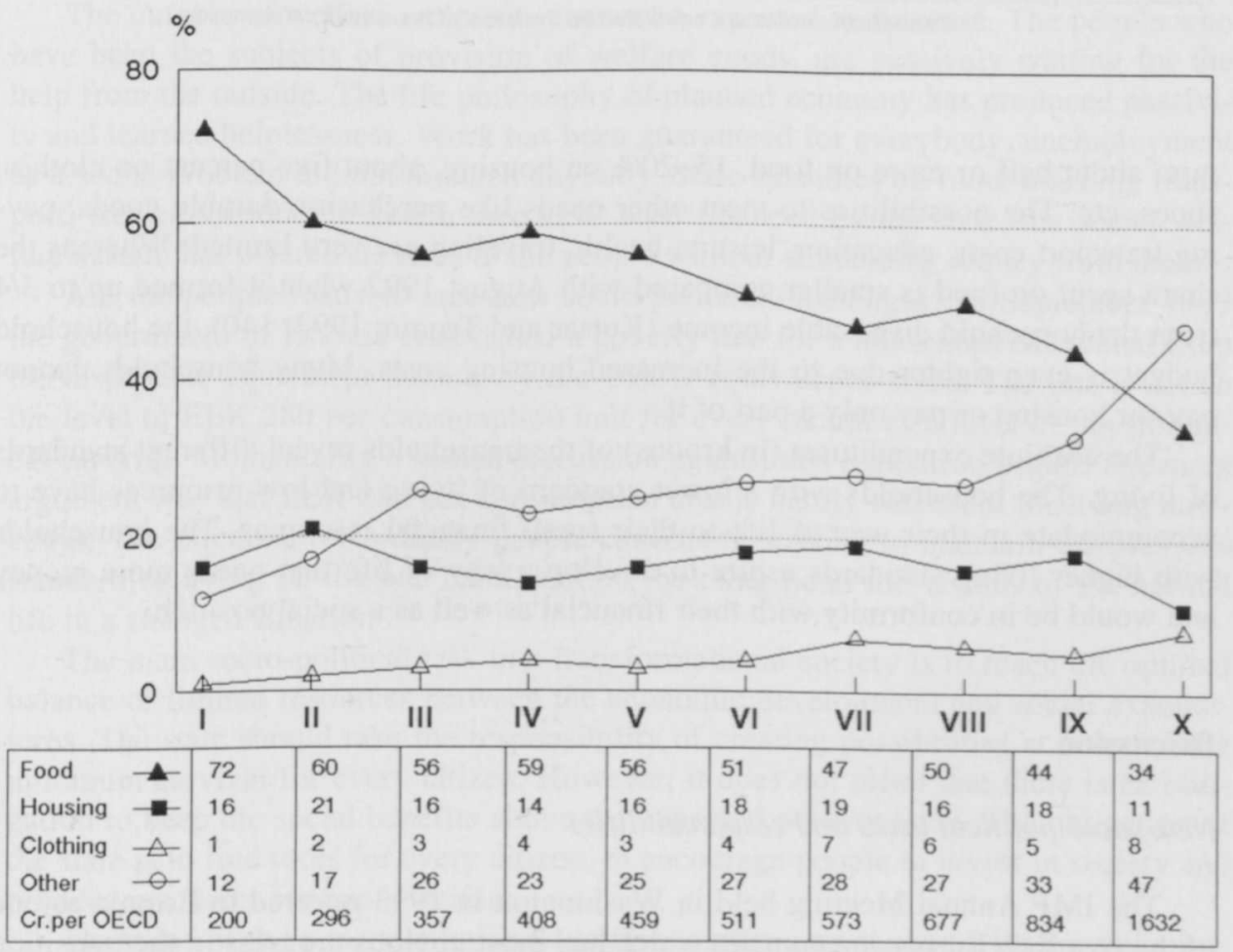

Household deciles are calculated on the basis of household consumption per OECD 
F ig u re 3. The structure of household consumption in expenditure deciles in January 1993.

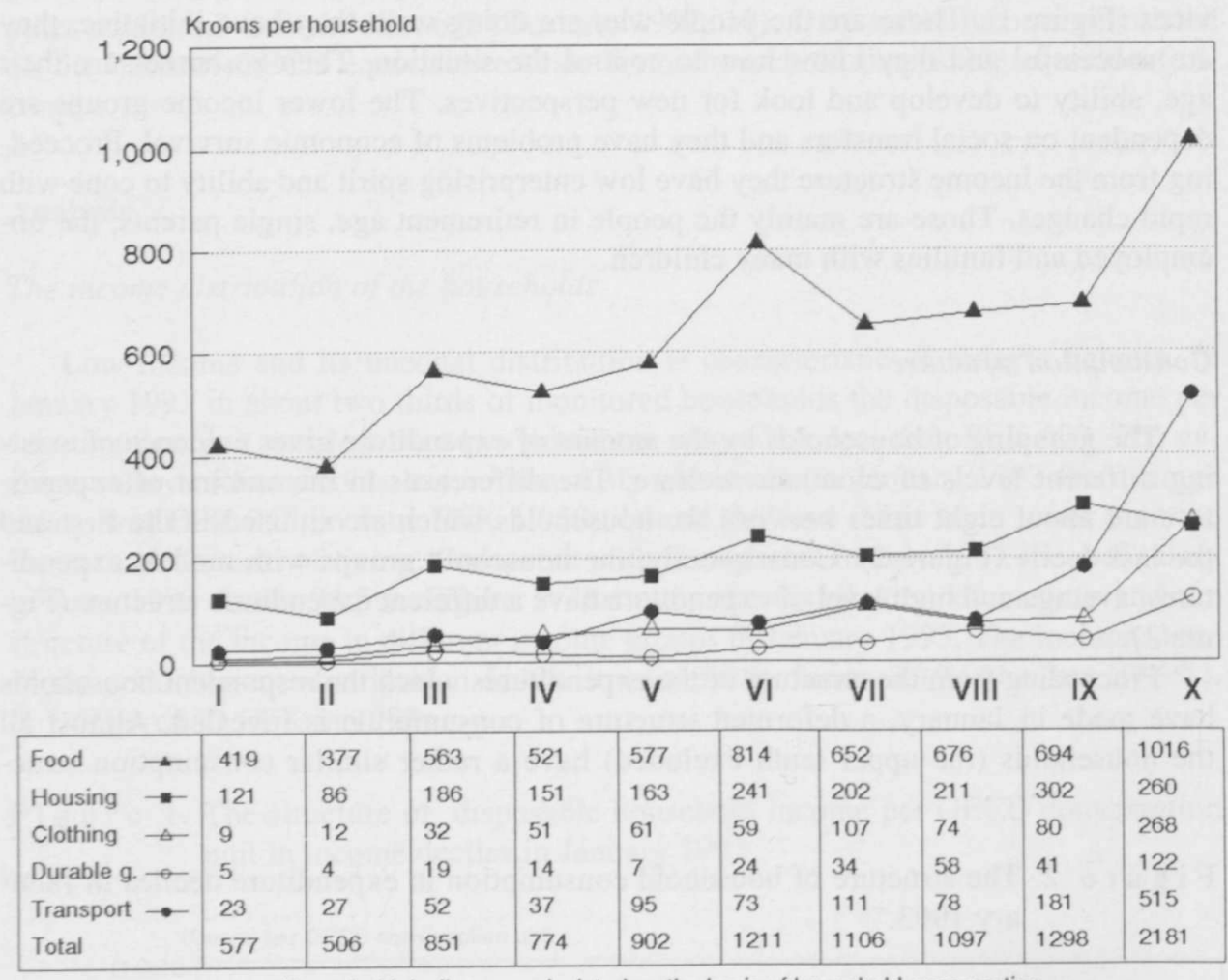

Household deciles are calculated on the basis of household consumption

ture: about half or more on food, $15-20 \%$ on housing, about five percent on clothes, shoes, etc. The possibilities to meet other needs like purchasing durable goods, paying transport costs, education, leisure, health, traveling are very limited. Whereas the share spent on food is smaller compared with August 1992 when it formed up to 3/4 from the household disposable income (Kutsar and Trumm 1993, 140), the household budget is even tighter due to the increased housing costs. Many households cannot pay for housing or pay only a part of it.

The absolute expenditures (in kroons) of the households reveal different standards of living. The households with a lower standard of living and low resources have to accommodate in their way of life to their small financial resources. The households with higher living standards aspire to develop a way of life that needs more money and would be in conformity with their financial as well as a social position.

\section{Discussion}

New socio-political tasks and responsibilities

The IMF Annual Meeting held in Washington in 1993 referred to Estonia as one of the five East European countries which had most obvious progress in the transition process. In accordance with the Report of IMF Mission the decrease in industrial pro- 
duction has stopped and probably will be replaced by a slight increase at the second half of 1993 . The inflation rate did not exceed $2-3 \%$ per month during the first quarter of this year. The foreign trade balance has been positive for the same period. The unemployment rate has remained lower than expected (by the prognosis it will reach $5-6 \%$ of the population of working age by the end of the year). The government pays special attention to the acceleration of the privatization process.

The share of households whose disposable income was lower than the cost of the minimum food basket (physiological minimum of survival) dropped from ten percent in August 1993 to $3.3 \%$ in January, at the same time, for the reason of increased level of minimum salary, $36 \%$ from the monitored households in January received income less than one minimum wage per person, in August 1992 correspondingly 26\% (Kutsar and Trumm 1993, 137).

Today people in Estonia make attempts to reach the normal society and by the quickest possible way to experience "western consumerism" formulated by Bob Deacon (1992). Some psychological preconditions for that purpose are patience and assiduousness of the Estonian character, appraisal of individual work and comparatively high educational level of the population. At the same time there are several factors setting limits to that process.

The major problems of the social sphere in a situation of limited resources are connected with the elaboration of social guarantees for less secure groups and the organization of social services proceeding from the new tasks and responsibilities. There are several groups of people who because of different reasons are dependent on the social welfare system or expect to receive social aid. Firstly, these are the people in retirement age, mothers taking maternity leave, handicapped, etc. They form a traditional group of people who in some way are dependent on the welfare system. Secondly, there are people who after having lost their job or permanent income unexpectedly find themselves among the group which at least, temporarily, needs social welfare services.

The number of welfare recipients cannot be expected to decrease. The people who have been the subjects of provision of welfare goods, are passively waiting for the help from the outside. The life philosophy of planned economy has produced passivity and learned helplessness. Work has been guaranteed for everybody, unemployment as a social problem did not threaten anybody. State subsidies on food, housing, transport, free education and health care have been financed by the state, the social welfare system has offered services to the people without demanding money from them.

Are the people ready to face new socio-political challenges? In September 1993 the government of Estonia established a poverty line for a household calculated from the disposable equivalent income by the OECD equivalence scale. The line is set on the level of EEK 280 per consumption unit for every month as a level of physiological survival. Momentarily a heated discussion against this regulation began. The main argument was that EEK 280 per consumption unit is hardly sufficient for living nowadays. The dilemma for ordinary people consists in striving to maintain the previous standard of living on the one hand, and on the other hand the visions of the normal life in a changed situation

The main socio-political task in a transformational society is to reach the optimal balance of limited resources between the economic development and social expenditures. The state should take the responsibility of creating possibilities at least for the minimum survival for every citizen. However, it does not mean that there is an obligation to keep the social benefits above the expected poverty level. The obligation of the state is to find tools for every citizen, to encourage people to invest in society and produce resources for one's welfare.

The ruins of the poor institutional welfare system cannot cope with the tasks formulated above. The situation of economic depression presumes sufficient cuts in the 
social welfare system. The most effective possibility for the restriction currently seems to be the application of the strategy of "cutting the cream on the cake", formulated by Heikkilä and Lehto $(1992,8)$. It means that the preserving only the "basic services" and "basic security" and cutting more heavily those sectors that are somehow special or used by better-off clients. The need for basic welfare services will be determined by means-test. This idea is derived from the liberal laissez-faire economics and is connected with the belief that such cuts will lead to a new path of economic growth (Wiman 1987, 34).

In conclusion, the transformation process in Estonia has led to a deep economic depression and the decrease of people's welfare. The new social situation creates problems of coping with everyday life for many people and households. People coming from the totalitarian system lack self-help mentality, they have to reform their whole life philosophy. The social policy is faced with the circumstances where response to the situation is needed. The question under discussion is how to meet the interests of the helpless without making any damage to the enterprising spirit of the economically successful people and economic progress in general.

The last socio-political developments in Estonia verify that the stake has been made on the economic development of the country. The general socio-political principle remains the same if compared with the pre-war independent times: the task of the state is to support disabled people who cannot work, the state does not take the responsibility of guaranteeing a minimum standard of living for everyone.

\section{References}

Deacon, B. (1992). East European welfare: past, present, future in comparative context. In: The New Eastern Europe: Social Policy, Past, Present and Future, edited by B. Deacon, pp. 1-30. SAGE Publications.

Dellenbrant, J.A. (1993). Democracy and poverty: the implementation of social reforms in the countries of central and eastern Europe. Scandinavian Journal of Social Welfare 2(3):150-157.

Ferge, Z. and Kolberg, J.E. ed. (1992). Social Policy in a Changing Europe. Campus/Westview: Boulder, Co.

Heikkilä, M. and Lehto, J. (1992). Adjustment or Crisis? Themes No 10. Helsinki: National Agency for Welfare and Health.

Kutsar, D. and Trumm, A. (1993). Poverty among households in Estonia. Scandinavian Journal of Social Welfare 2(3):128-141.

Marklund, S. (1993). Social policy and poverty in post-totalitarian Europe. Scandinavian Journal of Social Welfare 2(3):104-114.

Marody, M. (1992). Building a Competitive Society: Challenges for Social Policy. A background document for the International Seminar "Towards a Competitive Society in Central and Eastern Europe: Social Dimensions”. Kellokoski, Finland.

Uusitalo, H. (1992). The Scandinavian Welfare State and Poverty. Themes No 4. Helsinki: National Agency for Welfare and Health.

Wiman, R. (1987) From the Welfare State to a Welfare Society. Helsinki: National Board of Social Welfare. 